UNIVERSITY OF NOTTINGHAM

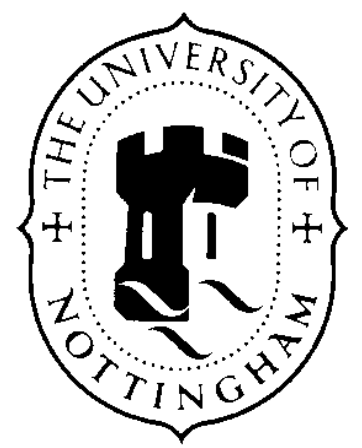

Discussion Papers in Economics

Discussion Paper

No. 00/15

\title{
THE DETERMINANTS OF CORPORATE DIVESTMENT IN THE UK
}

by Michelle Haynes, Steve Thompson and Mike Wright 


\section{UNIVERSITY OF NOTTINGHAM}

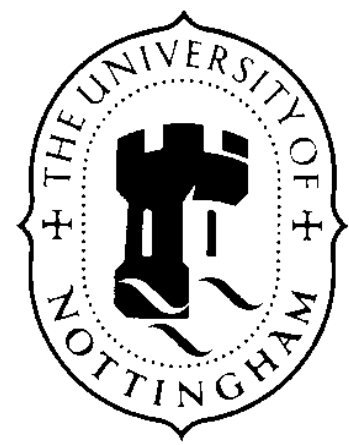

Discussion Papers in Economics

Discussion Paper

No. 00/15

\section{THE DETERMINANTS OF CORPORATE DIVESTMENT IN THE UK}

by Michelle Haynes, Steve Thompson and Mike Wright

Michelle Haynes is Research Associate, School of Economics, Mike Wright is Professor, Centre for Management Buy-out Research, Business School, both at the University of Nottingham, and Steve Thompson is Professor, Department of Economics, University of Leicester 


\title{
THE DETERMINANTS OF CORPORATE DIVESTMENT IN THE UK
}

\author{
Michelle Haynes $^{*}$, Steve Thompson ${ }^{* *}$ and Mike Wright ${ }^{* * *}$ \\ * Department of Economics \\ University of Nottingham \\ Nottingham, NG7 2RD \\ ** Department of Economics \\ University of Leicester \\ Leicester, LE1 7RH \\ **** Centre for Management Buy-out Research, \\ University of Nottingham \\ Nottingham, NG7 2RD
}

\begin{abstract}
It has been widely suggested that since the early 1980s many diversified firms narrowed the scope of their activities by refocusing on their core businesses, primarily through divestment activity. This study examines the extent and determinants of divestment across a large sample of UK firms over the period 1985 to 1989. Divestment is analysed using both a proportions and count data (Poisson and Negative Binomial regressions) approach. The results confirm that corporate divestment is not merely a reflection of managerial idiosyncrasies or mean reversion behaviour in the activities undertaken, but is a purposeful response to exogenous change in a manner broadly consistent with both the agency theoretic and strategic views of the firm.
\end{abstract}

\section{Acknowledgements}

Many useful comments on earlier versions of this paper were received from: Joachim Schwalbach, the editor, and two anonymous referees of the International Journal of Industrial Organization, Steve Davies, Dennis Mueller, Alessandro Sembenelli, Catherine Waddams and other participants at the 24th annual EARIE meeting in Leuven and the European Economic Association Conference, Toulouse, both in September 1997, and from Rod Falvey, Norman Gemmell and others at a staff seminar in the Economics Department, Nottingham University. Financial support from the ESRC ["Corporate Refocusing in the UK: An Empirical Analysis of its Causes and Consequences", grant R000236343] is acknowledged with gratitude.

\section{JEL Classification: G34, C25}

Key Words: Divestment, diversification, count data analysis, corporate refocusing *Corresponding Author. Tel./Fax: 0115 9514733/ 9514159. E-mail:

michelle.haynes@nottingahm.ac.uk 


\section{INTRODUCTION}

The purpose of this paper is to present an empirical analysis of the causes of corporate divestment activity in the UK, using a unique data set covering 1149 voluntary divestments across a sample of 141 large companies over the period 1985-1989. Compared to merger activity, which continues to receive an extensive scrutiny in the industrial organization and finance literatures, corporate divestment has attracted comparatively little academic interest, particularly outside the US. This situation appears anomalous. The underlying issues that motivate so much work on mergers namely the effectiveness of the market in corporate control and the efficiency consequences of altering the boundaries of the firm - would appear to apply with equal force to divestments. Furthermore, there is a widespread perception in the business press, supported by some evidence in the US context, that a substantial number of firms over the past 15 years or so have disposed of many peripheral activities to concentrate upon their core businesses. Gollop and Monahan (1991), for example, find a downturn in their indices of diversification for US manufacturing which is robust to changes in the level of aggregation of the data. Similarly, Markides (1995a), employing Rumelt's (1974) diversification typology on 210 of the leading Fortune US corporations, reports sharp falls in the numbers of related and unrelated diversifiers and corresponding growth in the numbers of firms in the single business and dominant business categories. This reduced diversification has been associated with widespread divestment in the US [Kaplan and Weisbach (1992); Ravenscraft and Scherer (1987)]. The fragmentary UK evidence available is also suggestive of high levels of voluntary divestment over the same period [see Geroski and Gregg (1997)], although the causes and consequences of this have received little attention.

This paper begins from the position adopted by recent American researchers [e.g., Hoskisson and Turk (1990), Hoskisson et al. (1994) and Markides, (1995a)] that widespread voluntary divestment is consistent with some exogenous environmental change which lowers the optimal level of diversification across the population of large firms. However, it is suggested here that existing attempts to explain intra-sample variations in the extent of divestment are methodologically unsatisfactory insofar as they typically employ the same hypotheses which have been used to explain prior levels of diversification to analyse subsequent changes in the same variable, or some proxy for it. For example, following in particular Mueller (1969) and Jensen (1986), it is widely considered that managers will have a preference for diversified expansion which may be realised in 
an environment of strong cash flow and weak corporate governance. In an apparent extension of this argument, researchers exploring divestment typically hypothesise that corporate governance ${ }^{1}$ variables intended to capture shareholder power with respect to managers, should decrease diversification and hence increase divestment. However, in the absence of any changes in these variables - and characteristics such as board composition and managerial shareholdings tend to be stable in the medium term - the same factors presumably have already acted to depress levels of diversification before any exogenous shock. Therefore it is unclear why such shareholder dominated firms should display higher rates of divestment than, say, firms whose managers enjoy greater discretion but which have had the corresponding opportunity to diversify more widely.

This paper treats divestment as an adjustment process through which the firm attains its optimal level of diversification. It allows that one or more of several factors may induce an initial downward shift in the optimal level of diversification. However, since divestment involves the transfer of real productive assets across markets where the number of potential buyers is typically small it is likely to involve transaction and dislocation costs, which are themselves influenced by the pace of the adjustment process. Therefore it appears unlikely that firms will make a full instantaneous response to any shock. Instead we hypothesise the existence of some form of partial adjustment mechanism. This implies that the observed divestment across some interval following the shock depends upon two factors: first, the impact of the shock itself on the optimal level of diversification; and second, the speed of adjustment which determines the extent of any potential change which is achieved over the observed interval. It is hypothesised that the potential change is largely determined by strategic factors within the firm whilst the speed of adjustment depends critically upon those performance and corporate governance characteristics which determine the firm's degree of insulation from capital market pressures.

The paper reports results from what we believe to be the first large-scale investigation of divestment activity outside the US. The project initially compiled a unique data set of corporate disposals, including demergers, sales to third parties and management buyouts, for a large sample of

\footnotetext{
${ }^{1}$ We follow Shleifer and Vishny (1997) in viewing corporate governance as dealing with: "the ways in which suppliers of finance to corporations assure themselves of getting a return on their investment." Therefore we denote as corporate governance characteristics those variables which would appear to determine the power of shareholders with respect to managers.
} 
UK firms during 1985-89, a period chosen to pre-date any recession-induced changes of the early 1990s [see Geroski and Gregg (1997)]. The paper then uses this database to construct measures of divestment based alternatively upon the proportion of assets divested and the number of recorded business unit sell-offs. Our hypotheses concerning the impact of strategic, corporate governance and performance factors are then used to construct a model to explain the observed incidence of diversification across the interval 1985-89. This is alternatively estimated using the proportions measure and count data analysis, employing Poisson and negative binomial distribution regressions, to explore the number of divestments.

\section{THEORETICAL CONSIDERATIONS}

\section{II.i The Causes and Timing of Divestments}

It has been widely established in a US context [e.g., Bhagat et al. (1990), Hoskisson and Turk, (1990), Shleifer and Vishny, (1991), Markides, (1995a,b), and Denis et al. (1997)] and conjectured in a UK one, that corporate refocusing, via voluntary divestment, has become a commonplace strategy since the early 1980s. An explanation for the existence, timing and extent of such a phenomenon requires an examination of two propositions: first, that each firm possesses an optimal level of diversification; and second, that a substantial number of firms found themselves to have breached this optimum, during the period in question, with the corresponding need to reduce the spread of their activities. These propositions are examined in turn:

First, in an environment of non-zero transaction costs, multi-output firms may be considered to exist to economise on the costs of using markets. Williamson (1975) described the benefits of bringing vertically related activities under common ownership. More recently, transaction cost economics [Teece (1982)] and the resource-based theory of the firm [Wernerfelt (1984), Barney (1986), Ingham and Thompson (1995)] have emphasised the gains that may accrue when a firm diversifies to exploit under-utilised, imperfectly imitable specific assets. However, expansion brings with it organisational costs. Size and diversity increase the informational problems that hierarchies need to address. Informational transfers across hierarchical levels generate control loss problems which limit the viable height of organisational hierarchies, while intra-firm transactions may inhibit hierarchical decomposition. In general, increasing firm size will require decentralisation of decision- 
making, as exemplified in the M-form described by Williamson (1975), but decentralised structures are not without their own difficulties - see below. Furthermore, as Penrose (1959) demonstrated, the very indivisibilities in factor supply which generate the potential for economies of scope also constrain internal expansion. Surplus capacities are unlikely to be uniform across firm-specific assets and bottlenecks will occur, particularly in the availability of managerial resources, causing organisational costs to rise with further expansion.

The foregoing discussion suggests that diversification brings performance benefits to the firm and hence value gains to its owners, but that such benefits are subject to decreasing returns as organisational costs rise. That is ceteris paribus the value of the firm (V) is a concave function of the level of diversification (D). However, agency theory suggests that senior managers may derive direct benefits from diversification in at least two ways: first, because it will reduce the variability of a firm's earnings thus lowering the risk attached to the managers' firm-specific human capital [Amihud and Lev (1981)]; and second, because, following Mueller (1969) and Jensen (1986), it has been seen as a means of facilitating growth in firms whose core activities have a strictly limited potential for expansion. Jensen (1986), for example, argues that firms in mature but profitable industries, which generate cash flows in excess of those needed for reinvestment, will systematically over-diversify. Thus it appears reasonable to expect that both $\mathrm{V}$ and $\mathrm{D}$ enter the managerial utility function.

Three inter-related arguments have been advanced in the literature to explain downward displacement in optimal diversification levels since the early 1980s:

First, Jensen (1986) and others have argued that capital market innovations - particularly including debt-financed takeovers, the use of hostile bid advisers, the emergence of venture capitalists to finance management buyouts etc. - have increased the effectiveness of the market for corporate control. This in turn, it is suggested, has not merely reduced the ability of managers to divert free cash flow to preferred - but unprofitable - diversifications, but encouraged them to divest and disinvest in loss-making activities.

Second, a combination of capital market innovations and the lowering of transaction costs may have reduced the comparative advantage of the multidivisional form of organisation. It has been 
argued by Bhide (1990) and others that external capital market evolution has attenuated the informational advantage of the M-form's internal capital market, as described by Williamson (1975). In addition, the growth of the contracting out of supply and support functions within the private sector attests to the fall in transaction costs. Survey evidence [e.g., Geroski and Gregg (1997)] confirms the reduced popularity of the M-form among large UK firms. Arguments such as these point to a backward shift in the value-diversification function.

Third, there is growing evidence that the capital market itself came to take a more negative view of diversified firms during the 1980s. It appears that an optimistic stance with respect to conglomerate mergers in the 1960s and 1970s [Morck et al. (1990), Shleifer and Vishny (1991)] gave way to a more pessimistic viewpoint as the evidence accumulated [Ravenscraft and Scherer (1987)], leading to a preference for more narrowly focused firms in the 1980s [Wernerfelt and Montgomery $\left.(1988)^{2}\right]$. Markides $(1995 a, b)$ notes that even managers motivated purely by shareholder value considerations could find themselves with an over-diversified firm in these circumstances.

\section{$\underline{\text { II.ii Divestment as a Process of Adjustment }}$}

Assume that the managers of firm $i$ are operating with an equilibrium level of diversification when some exogenous change occurs in the firm's environment which causes a shift in desired diversification from $D_{i}$ to $D *_{i}$. Since this paper is primarily concerned with corporate divestment as an adjustment to such a change we remain agnostic, for the moment, about its proximate cause. However, following on from the previous discussion this could involve either an increase in the effectiveness of the capital market as a disciplinary device or a downward revision by the capital market in the assessment of the benefits of multi-output operations, or some combination of these. Managers may be expected to respond to their new circumstances by divesting activities. However, the literature on divestment indicates that this typically occurs only with some considerable delay ${ }^{3}$.

\footnotetext{
${ }^{2}$ Lang and Stultz (1994) extend the Wernerfelt and Montgomery (1988) methodology to examine the implied diversification discount using firm and industry values for Tobin's $q$. They report the existence of a statistically significant discount as far back as 1978. Servaes (1996) has recently detected such a discount in the 1960s, but he finds that it disappeared in the 1970s during the era of conglomerate expansion.

${ }^{3}$ For example, Denis et al. (1997) examined the timing of voluntary divestments in the US and report significant falls in firm value for three years prior to the divestment. They summarise: "We thus conclude that the sample changes in diversification are not timely responses to sudden changes in the value of diversification." (p. 157) Similarly, the literature on the relationship between acquisitions and divestments [e.g., Ravenscraft and Scherer (1987), Kaplan and Weisbach (1992)] suggests that many acquisitions are
} 
This is scarcely surprising. Locating and negotiating with potential buyers for specific corporate assets may be problematic, whilst rapid change may imply high organizational costs, not least for the managers themselves ${ }^{4}$. This suggests that the observed divestment over the succeeding interval will depend upon two effects: first, the speed with which managers have to respond to capital market discipline; and second the extent to which the new optimal level of diversification diverges from the previous equilibrium. For representational purposes this may be written as:

$\Delta \mathrm{D}_{\mathrm{it}}=\lambda_{\mathrm{i}}\left(\mathrm{D}_{\mathrm{it}-1}-\mathrm{D}^{*}{ }_{\mathrm{it}}\right)$

where $\Delta D_{i t}$ is the observed period divestment, $\lambda_{\mathrm{i}}$ is a firm-specific lagged adjustment operator and $\left(D_{i t-1}-D^{*}{ }_{i t}\right)$ is the divergence between the desired and (start of period) actual levels of diversification.

It is conjectured here that $\lambda_{\mathrm{i}}$ will be negatively related to the firm's insulation from capital market pressures. Thus, for example, corporate governance characteristics and factors determining the managers' security from takeover threat will influence adjustment and hence divestment in the event of a disequilibrium level of diversification. Given the capital market changes described above and the findings of the empirical literature in the US [see Markides (1995a), Bergh (1997), etc.] it is assumed that the extent of any such divergence between desired and actual diversification will be primarily determined by the strategic and market characteristics of the firm (size, market structure etc.).

It was considered that identification problems and issues of endogeneity with firm-level variables made it infeasible to specify and estimate a satisfactory structural model of the

unsuccessful and subsequently divested, but frequently only after an extended period. Their results also suggest that the median holding period for subsequently divested acquisitions fell consistently across the period 19711982, from over 15 years in 1971-72 to approximately 5 years in 1981-82.

4 The assumption of a time-cost trade off in altering the configuration of the firm's activities is entirely consistent with the existing literature on diversification and divestment. Penrose (1959) provides the classic explanation of the costs of over-rapid expansion, whilst comparisons of voluntary and involuntary divestment point to the superiority of the former for the vendor's shareholders, suggesting that enforced sell-offs restrict the vendor's ability to locate and negotiate with buyers with a high willingness to pay. However, being overdiversified also imposes costs insofar as it disappoints the capital market with implications for the firm's cost of capital and the managers' expectations with respect to the takeover threat. We assume that good performance, 
divestment process. Instead we adopted the approach of estimating a reduced form equation in which divestment across the interval was examined using prior values of the governance and strategic variables. The estimation approach imposes a common lagged adjustment operator for each firm (i.e. $\lambda_{\mathrm{i}}=\lambda$ ). This is a necessary assumption for cross-sectional work ${ }^{5}$.

Divestment $_{\mathrm{i}}=\alpha_{0}+\alpha_{1}$ Firm Performance $_{\mathrm{i}}+\alpha_{2}$ Leverage $_{\mathrm{i}}+\sum_{j=1}^{3} \alpha_{2+\mathrm{j}}$ Corporate Governance

Variables $_{\mathrm{ij}}+\alpha_{6}$ Diversification $_{\mathrm{i}}+\alpha_{7}$ Size $_{\mathrm{i}}+\alpha_{8}$ Market Share $_{\mathrm{i}}$

$+\alpha_{9}$ Concentration $_{\mathrm{i}}+\alpha_{10}$ Management Change $_{\mathrm{i}}+\alpha_{11}$ Acquisition $_{\mathrm{i}}+\varepsilon_{\mathrm{i}}$

The explanatory variables are as follows:

Firm Performance has been widely shown to be negatively related to the contemporaneous probability of being taken over - see Palepu (1986), Markides (1995b) for a discussion - and hence would appear to convey partial insulation from the capital market's discipline. Thus, divestment should increase as firm performance decreases.

Leverage, following Jensen (1986), may be considered to reduce managerial discretion insofar as it precommits cash flows to meet debt servicing obligations. Ceteris paribus, higher levels of leverage were expected to increase the pressure on sluggish managers to reduce diversification, not least because divestments can be used to pay off debt.

Corporate Governance arrangements function so as to make managers more responsive to the interests of the shareholders. Therefore the more effective the institutions of governance in place the faster should be the speed of adjustment. Here we employ a vector of widely recognised

low leverage and weak corporate governance (i.e. weak shareholder to manager power) reduce capital market discipline and allow managers a more leisurely adjustment regime.

${ }^{5}$ Further work employing panel data is being undertaken which allows for firm-specific effects to be captured. It is possible that $\lambda$ will diverge across companies but beyond the governance and strategic characteristics investigated here it is difficult to model a priori. There may be circumstances where substantial firm-specific differences may be expected e.g. firms may consciously adopt policies of repositioning their product mix. However, examination of these issues would require a separate questionnaire survey of executives in the firms concerned which is beyond the scope of this paper. 
corporate governance variables including: management equity ownership, board composition and the existence or otherwise of an identifiable (large) blockholder [e.g., Gibbs (1993), Johnson et al. (1993)]. Corporate governance arrangements are predicted to be positively related to divestment.

The second source of variation in observed divestment across the sample is assumed to arise from the deviation of each firm's actual and optimal levels of diversification. This, it is conjectured, depends principally on strategies deployed prior to whatever exogenous shock has now occurred. Thus initial diversification and size were expected ceteris paribus to increase the distance between the actual and desired levels. Size is included both as a proxy for organizational costs, and hence as an indication of the potential for "downsizing" in a period of falling transactions costs, and also as a necessary control regressor in the count data estimations since the number of potential disposals will be a function of size ${ }^{6}$. Both initial diversification and firm size are predicted to be positively related to subsequent divestment activity.

Core product market characteristics have often been considered to drive diversification into new activities. Thus high values of market share and concentration in a firm's core market simultaneously raise its profitability whilst reducing the potential for core expansion. These are precisely the conditions under which size-motivated managers might be expected to pursue diversifying expansions. Therefore, by extension, these conditions might be expected to discourage such managers from divestment even where capital market sentiment favoured more tightly focused firms. However, Markides (1995a) argues conversely that core market conditions such as market share and concentration determine the attraction of a refocusing strategy and hence impact positively on divestment. Which of these two effects will dominate cannot be determined ex ante, so the relationship between divestment and market structural characteristics is ambiguous. Empirical evidence in the US [e.g., Chatterjee and Wernerfelt (1991), Chang (1996)] largely confirms the importance of these factors. Of course, the same variables may be considered as key determinants of firm performance and hence to work through that construct on the speed of adjustment.

\footnotetext{
${ }^{6}$ That is, simple mean-reversion behaviour implies that $\Delta \mathrm{D}_{\mathrm{it}}=\mathrm{k}\left(\mathrm{D}_{\mathrm{it}-1}\right)$ where $\mathrm{k}^{\prime}>0$.
} 
Whilst the strategy (diversification and size) and product market variables (primary market share and primary market concentration) were taken at their start-of-period value to avoid possible simultaneity problems, two additional binary controls were included for within-period changes. These were: first, a senior management change variable, which almost by definition is exogenous to the existing decision takers, and which was expected to lower the desired level of diversification; and second, an acquisition variable which appeared a necessary control since any additional acquisition raises the stock of potentially divestable businesses ${ }^{7}$ and is predicted to be related positively to divestment.

\section{DATA AND METHODS}

\section{III.i Data \& Variables}

The initial sample of firms used in this study are 141 UK firms randomly selected from the 1985 FT500 list. Financials, foreign-owned and trading companies were excluded from the study because of problems of comparability with other firms. Information regarding parent-to-parent divestments and acquisitions was obtained from 'Acquisitions Monthly' and 'The Financial Times' from 1985 to 1989. Information on divestment to management buyouts was obtained from 'The Centre for Management Buyout Research' database compiled by one of the authors [see for example, Wright et al. (1994) for details].

The extent of divestment activity is separately measured using the proportion of assets divested and the number of business units divested. The rationale for using separate measures rests on both methodological and practical reasons. The count data specification, using the number of recorded divestments, relates more obviously to any control problems associated with diversity. Furthermore, this approach is advantageous in so far as value data are inevitably unobtainable for some smaller divestments. Divestment expressed as a proportion of the firm's initial assets represents a measure of the importance of divestment activity over the period.

\footnotetext{
7 There are, of course, further reasons why we might expect a relationship between divestment activity and (prior) mergers: first, unsuccessful mergers, perhaps initially driven by managerial preference or hubris, may have to be reversed; second, in an era of multi-output firms an acquisition to secure a position in industry A might bring with it an unwanted past expansion into industry B, with the corresponding need for a divestment.
} 
The proportion of assets divested is calculated as the sales price of divested units divided by market value for the previous year. These percentages are summed over the period to obtain a total percentage of assets divested (this can and does exceed one hundred per cent in the case of firms who were active divestors and acquirers over the period). In the cases where a sales price was unreported, a proportion of 0.1 per cent of market value was assigned to that divestment ${ }^{8}$. Alternative assumptions were made but the results appeared insensitive to the allocation rule selected. The number of business units divested is the total number of sell-offs recorded over the period. Altogether a total of 1149 voluntary divestments was reported. (Involuntary divestments were excluded. $)^{9}$ On average, each firm made 1.6 divestments per year, representing 4.4 per cent of its assets in the previous year.

Data on firm performance, leverage variables and firm size were taken from the Datastream database which holds information on quoted companies. Corporate governance variables, a change in management and diversification indices ${ }^{10}$ were constructed from company annual reports. Market share and concentration figures were constructed using information on firm and industry sales taken from Datastream. Definitions and methods of construction of these variables are given in Appendix A. From this sample, seven firms were eliminated due to incomplete data coverage, reducing the final number of firms with all necessary data to 134 .

\section{III.ii Methodology}

\footnotetext{
${ }^{8}$ It appears reasonable to assume that the overwhelming majority of divestment deals for which no price is recorded in either the firm's annual accounts or in one of our secondary sources, lie in the lower tail of the divestment size distribution. In general our secondary sources use some size criterion and do not supply full data for very small (e.g. $<£ 1 \mathrm{~m}$ in the case of Acquisitions Monthly) transactions. Therefore identified but unpriced deals will tend to fall into this category.

${ }^{9}$ Such divestments in any case were an insignificant part of the UK market until 1989 when "divestment deals" were introduced as part of the change in merger policy.

${ }^{10}$ It is recognised that constructing firm-level diversification measures is inevitably problematic: First, the firm's description of its activities is subjective and mapping these into the SIC is not always straightforward; Second, ours is a purely statistical measure of the concentration of the firm's revenues from the product markets in which it participates. It makes no attempt to distinguish the technological or market relatedness which may exist between a firm's activities under two or more 3-digit SIC codes; Third, it is necessary to select a diversification measure from the wide range of indices available. In the event we found that the principal alternative measures, including the Herfindahl, were highly intercorrelated and the entropy measure was employed for comparability with earlier work. This is consistent with Markides (1995b).
} 
The empirical analysis of divestment examines both the proportionate value and the number of activities divested. While the former is indicative of the magnitude of the firm's divestment strategy, it is highly sensitive to single decisions involving very large disposals. (Furthermore, in some cases the asset sale price will become inflated by the buyers' willingness to overpay.) The second divestment measure, the number of recorded disposals, has the advantage of making full use of the data available without our having to assign values to those disposals where there was no recorded sale price. Both versions of the divestment measure give rise to limited dependent variable estimation. In the proportions case an OLS log-linear model is used. The count data version employs alternative specifications based upon the Poisson and negative binomial distributions, respectively. It is contended here that the two approaches are complementary and necessary given the nature of the data on divestment. While the proportions model is straightforward, the count data models are probably less familiar and are described below.

\section{The Poisson and Negative Binomial Models}

The Poisson distribution is widely used in analysing count data where the dependent variable is discrete and defined for non-negative integers corresponding to the number of events occurring in a given interval [e.g., Hausman et al. (1984)]. We model the number of divestments, $\mathrm{y}_{i}$, as being generated by the following Poisson process: Prob $\left(\mathrm{y}_{i}\right)=\lambda_{i}^{\mathrm{yi}} \mathrm{e}^{-\lambda i} / \mathrm{y}_{i}$ !, where $\lambda_{i}$ is the conditional mean and variance of the Poisson distribution. To incorporate explanatory variables $\mathrm{X}_{i}$, the most common formulation for $\lambda_{i}$ is: $\ln \lambda_{i}=\mathrm{X}_{i} \mathrm{~b}$. Parameter estimates are obtained by solving the loglikelihood function using maximum likelihood techniques: $\ln \mathrm{L}=\Sigma\left(\mathrm{y}_{i} \mathrm{X}_{i} \mathrm{~b}-\lambda_{i}-\ln \mathrm{y}_{i}\right.$ !).

One restriction of the basic Poisson model is the imposition of an equal conditional mean and variance. In many economic applications, it is not uncommon to find that the variance of $\mathrm{y}_{i}$ exceeds the mean, implying 'overdispersion' in the data. Overdispersion may occur if there is unobserved heterogeneity or interdependence between the occurrence of successive events. An important consequence of fitting overdispersed data to the Poisson model is that the estimated covariance matrix will be biased downwards, producing spuriously small estimated standard errors of the parameter estimates and overstated $t$-statistics. 
A solution to the problem of overdispersion is to use a distribution that allows for a less restricted variance function. To this end the negative binomial model has been proposed as a useful alternative to the Poisson model [Cameron and Trivedi (1986)]. The negative binomial model allows for unobserved heterogeneity in the mean function by introducing an additional stochastic component to $\lambda_{i}: \ln \lambda_{i}=\mathrm{X}_{i} \mathrm{~b}+\varepsilon_{i}$, where $\varepsilon_{i}$ captures unobserved heterogeneity and is uncorrelated with the explanatory variables. The model can be derived by assuming $\lambda_{i}$ to be distributed randomly and to follow a gamma distribution of the form: $f\left(\lambda_{i}\right)=1 / \Gamma(1 / \alpha)^{1 / \alpha} \mathrm{e}^{-\lambda i / \alpha} \lambda_{i}^{1 / \alpha-1}$.

By choosing the particular form of gamma distribution given above, one obtains a model which has the same conditional mean as the Poisson model but allows overdispersion since: $\operatorname{var}\left(\mathrm{y}_{i} \mid \mathrm{X}_{i} \mathrm{~b}\right)=$ $\lambda_{i}\left(1+\alpha \lambda_{i}\right)>\operatorname{var}\left(\mathrm{y}_{i} \mid \mathrm{X}_{i} \mathrm{~b}\right)=\lambda_{i}$. Since the mean equals the variance when $\mathrm{y}_{i}$ is Poisson distributed, the natural basis for testing the adequacy of the Poisson model is to propose tests of the form $\alpha=0$.

\section{RESULTS}

The descriptive statistics and inter-correlations of the variables used in the study are given in Table 1. An inspection of these for the number of divestments provides a priori evidence of overdispersion in the data, since the variance is appreciably larger than the mean. This indicated the importance of testing for the validity of the Poisson specification in the regression model which follows. 
Table1. Means, standard deviations and correlations

\begin{tabular}{|c|c|c|c|c|c|c|c|c|c|c|c|c|c|c|c|c|c|c|c|c|c|}
\hline Independent Vars. & Mean & S.D. & 1. & 2. & 3. & 4. & 5. & 6. & 7. & 8. & 9. & 10. & 11. & 12. & 13. & 14. & 15. & 16. & 17. & 18. & 19. \\
\hline 1. $\%$ divested & 21.77 & 28.96 & & & & & & & & & & & & & & & & & & & \\
\hline 2. No. divestments & 8.149 & 8.573 & 0.702 & & & & & & & & & & & & & & & & & & \\
\hline 3. ROCE & 18.01 & 6.856 & -0.17 & -0.13 & & & & & & & & & & & & & & & & & \\
\hline 4. ROE & 14.27 & 8.345 & -0.08 & 0.007 & 0.843 & & & & & & & & & & & & & & & & \\
\hline 5. $\mathrm{ROS}$ & 7.553 & 4.523 & -0.07 & -0.02 & 0.457 & 0.448 & & & & & & & & & & & & & & & \\
\hline 6. Tobin's q & 1.133 & 0.836 & -0.19 & -0.15 & 0.560 & 0.464 & 0.353 & & & & & & & & & & & & & & \\
\hline 7. Debt to assets & 27.28 & 13.12 & 0.220 & 0.299 & -0.22 & 0.088 & -0.14 & -0.11 & & & & & & & & & & & & & \\
\hline 8. Debt-to-equity & 0.492 & 0.467 & 0.157 & 0.247 & -0.18 & 0.073 & -0.13 & -0.14 & 0.844 & & & & & & & & & & & & \\
\hline 10. Blockholder & 0.745 & 0.438 & 0.042 & -0.06 & 0.089 & 0.052 & -0.04 & 0.034 & 0.061 & 0.053 & 0.171 & & & & & & & & & & \\
\hline 11. Board composition & 0.628 & .0592 & -0.03 & 0.011 & -0.17 & -0.17 & -0.08 & -0.14 & 0.056 & 0.012 & -0.200 & -0.060 & & & & & & & & & \\
\hline 12. Top management & 0.709 & 0.456 & 0.102 & 0.077 & -0.06 & -0.13 & -0.01 & -0.08 & -0.10 & -0.06 & -0.160 & -0.180 & 0.112 & & & & & & & & \\
\hline 13. Entropy index & 0.896 & 0.498 & 0.398 & 0.369 & -0.18 & -0.07 & -0.01 & -0.37 & 0.285 & 0.229 & -0.240 & -0.180 & 0.122 & 0.039 & & & & & & & \\
\hline 14. Total assets & 796606 & 2227886 & 0.061 & 0.277 & -0.06 & -0.03 & 0.070 & -0.15 & 0.050 & 0.075 & -0.110 & -0.030 & 0.098 & -0.04 & 0.157 & & & & & & \\
\hline 15. Total sales & 1558958 & 4156668 & 0.049 & 0.274 & -0.02 & -0.04 & 0.008 & -0.10 & 0.054 & 0.066 & -0.090 & -0.120 & 0.099 & 0.010 & 0.127 & 0.981 & & & & & \\
\hline 16. No. employees & 27210 & 36449 & 0.179 & 0.449 & -0.06 & -0.03 & 0.023 & -0.11 & 0.080 & 0.066 & -0.100 & -0.140 & -0.07 & -0.09 & 0.272 & 0.626 & 0.627 & & & & \\
\hline 17. Acquisition & 0.977 & 0.148 & 0.116 & 0.137 & 0.080 & 0.047 & 0.140 & -0.021 & 0.068 & 0.036 & -0.291 & -0.088 & 0.289 & -0.091 & 0.266 & 0.045 & 0.038 & 0.112 & & & \\
\hline 18. Market share & 0.243 & 0.272 & 0.014 & 0.203 & 0.003 & -0.045 & 0.053 & 0.012 & 0.056 & 0.058 & -0.073 & -0.128 & -0.125 & 0.012 & 0.169 & 0.287 & 0.254 & 0.358 & -0.124 & & \\
\hline 20. Shareholder return & 1.265 & 0.289 & 0.214 & 0.194 & 0.149 & 0.263 & 0.178 & -0.112 & 0.113 & 0.121 & -0.019 & -0.189 & 0.015 & -0.160 & 0.169 & 0.044 & 0.051 & 0.091 & 0.270 & -0.210 & -0.246 \\
\hline
\end{tabular}


Equation (2) was estimated using the proportion of assets divested and the number of divestments as alternative versions of the dependent variable. The results are reported in Tables 2 and 3 respectively. Since the sample statistics led us to suspect overdispersion in the data, we tested the moment restriction implied by the Poisson model using the regression-based approach suggested by Cameron and Trivedi (1990). This is based on the weighted least squares estimation of $\left(y_{i}-\mu_{i}\right)^{2}-\mu_{i}$ on $\mathrm{g}\left(\mu_{\mathrm{i}}\right)$, where $\mathrm{g}\left(\mu_{\mathrm{i}}\right)$ is some specified function and $\mu_{\mathrm{i}}$ is the predicted mean from the Poisson regression. The Poisson model is rejected if the coefficient on $\mathrm{g}\left(\mu_{\mathrm{i}}\right)$ is significantly different from zero. Cameron and Trivedi (1990) suggest two possibilities for $g\left(\mu_{\mathrm{i}}\right): \mathrm{g}\left(\mu_{\mathrm{i}}\right)=\mu_{\mathrm{i}}$ and $\mathrm{g}\left(\mu_{\mathrm{i}}\right)=\mu_{\mathrm{i}}{ }^{2}$. Using ROCE as the measure of firm performance, these yielded $t$-ratios of 6.24 and 7.61 respectively which were highly significant and suggested a rejection of the Poisson model. Rejection of the mean-variance equality led us to re-estimate the regression using the negative binomial model. The Wald statistic for testing the Poisson model against the negative binomial model is 5.745 pointing to the superiority of the latter. This conclusion was reinforced by the likelihood ratio statistic of 209.434 [ 2 x (491.285 - 386.568)]. This conclusion was robust to specification changes involving the alternative size, leverage and firm performance variables. However, it is the case that the two alternative functional forms gave very similar parameter estimates and differed largely because the lower variance in the Poisson model has the effect of downwardly biasing the coefficients' standard errors. Table 3 gives illustrative Poisson estimates for comparative purposes, but the following discussion of the count data results relates to the negative binomial results, which we consider to be the more reliable.

In several cases we had generated alternative versions of the independent variables: thus firm size was alternatively measured as the logarithms of total employees, total assets and total sales, leverage as the debt-to-assets and debt-to-equity ratios and firm accounting performance as return on capital employed (ROCE), return on equity (ROE) and return on sales (ROS). Inevitably, in each case the alternatives were highly correlated, as seen in Table 1 . The reported results, in Tables 2 and 3, use ROCE as the firm-specific performance measure, debt-to-assets as the leverage variable and $\log$ of the number of employees as the firm size indicator. The alternative measures yielded very similar estimates ${ }^{11}$.

\footnotetext{
${ }^{11}$ These results are available from the authors.
} 
Table 2. The Determinants of the Intensity ${ }^{\mathrm{a}}$ of Divestment: OLS Estimates

\begin{tabular}{|c|c|c|c|c|}
\hline Constant & $\begin{array}{l}-15.682 \\
* * * \\
(-3.444)\end{array}$ & $\begin{array}{l}-15.709 \\
* * * * \\
(-4.144)\end{array}$ & $\begin{array}{l}-15.542 \\
* * * * \\
(-4.112)\end{array}$ & $\begin{array}{l}-14.391 \\
* * * * \\
(4.050)\end{array}$ \\
\hline Accounting performance & $\begin{array}{r}-0.354 \\
(-0.468)\end{array}$ & & & \\
\hline Relative accounting performance & & $\begin{array}{r}0.021 \\
(0.502)\end{array}$ & & \\
\hline Market performance & & & $\begin{array}{r}-0.049 \\
(-0.130)\end{array}$ & \\
\hline Relative shareholder returns & & & & $\begin{array}{l}-0.001 \\
(0.910)\end{array}$ \\
\hline Firm leverage & $\begin{array}{r}1.119 \\
* * * * \\
(2.794)\end{array}$ & $\begin{array}{r}1.191 \\
* * *(3.011)\end{array}$ & $\begin{array}{r}1.161 \\
* * * * \\
(2.968)\end{array}$ & $\begin{array}{r}1.073 \\
* * * * \\
(2.805)\end{array}$ \\
\hline Board composition & $\begin{array}{r}0.131 \\
*(1.673)\end{array}$ & $\begin{array}{r}0.126 \\
*(1.713)\end{array}$ & $\begin{array}{r}0.127 \\
*(1.725)\end{array}$ & $\begin{array}{r}0.116 \\
*(1.721)\end{array}$ \\
\hline Blockholder & $\begin{array}{r}-0.600 \\
(-0.978)\end{array}$ & $\begin{array}{r}-0.608 \\
(-0.991)\end{array}$ & $\begin{array}{r}-0.586 \\
(-0.945)\end{array}$ & $\begin{array}{c}-0.558 \\
(0.928)\end{array}$ \\
\hline Management equity & $\begin{array}{r}0.282 \\
* *(2.353)\end{array}$ & $\begin{array}{r}0.282 \\
* * \\
(2.364)\end{array}$ & $\begin{array}{r}0.285 \\
* *(2.361)\end{array}$ & $\begin{array}{r}0.261 \\
* *(2.193)\end{array}$ \\
\hline Diversification level & $\begin{array}{r}0.220 \\
* * * \\
(2.785)\end{array}$ & $\begin{array}{r}0.226 \\
* * * * \\
(2.888)\end{array}$ & $\begin{array}{r}0.229 \\
* * * * \\
(2.751)\end{array}$ & $\begin{array}{r}0.240 \\
* * * \\
(3.145)\end{array}$ \\
\hline Firm size & $\begin{array}{r}0.549 \\
* *(1.734)\end{array}$ & $\begin{array}{r}0.577 \\
*(1.812)\end{array}$ & $\begin{array}{r}0.566 \\
*(1.756)\end{array}$ & $\begin{array}{r}0.664 \\
* * * \\
(2.335)\end{array}$ \\
\hline Market share & $\begin{array}{r}0.400 \\
(1.409)\end{array}$ & $\begin{array}{r}0.389 \\
(1.372)\end{array}$ & $\begin{array}{r}0.388 \\
(1.358)\end{array}$ & ${ }^{*}(1.643)$ \\
\hline Concentration & $\begin{array}{r}-1.010 \\
* * 1.892)\end{array}$ & $\begin{array}{r}-0.958 \\
*(-1.767)\end{array}$ & * ${ }^{-0.996}$ & ${ }^{* * * *}(2.917)$ \\
\hline Change in management & $\begin{array}{r}1.406 \\
* *(2.313)\end{array}$ & ${ }^{* *}(2.411)$ & $\begin{array}{r}1.442 \\
{ }^{* *}(2.372)\end{array}$ & ${ }^{* *}(2.360$ \\
\hline Acquisition & $\begin{array}{r}4.689 \\
* * * \\
(2.129)\end{array}$ & $\begin{array}{r}4.495 \\
* * * \\
(2.049)\end{array}$ & $\begin{array}{r}4.525 \\
* *(2.034)\end{array}$ & $\begin{array}{r}3.991 \\
*(1.876)\end{array}$ \\
\hline $\mathrm{R}^{2}$ & 0.356 & 0.357 & 0.355 & 0.380 \\
\hline
\end{tabular}

Notes: $\mathrm{n}=134 ; t$-statistics appear in parentheses: ${ }^{*}=p<0.1,{ }^{* *}=p<0.05,{ }^{* * *}=p<0.01$.

${ }^{\mathrm{a} D e p e n d e n t ~ v a r i a b l e ~ e q u a l s ~ t h e ~ p r o p o r t i o n ~ o f ~ a s s e t s ~ d i v e s t e d ~ i . e . ~}$

$$
\sum_{t=1985}^{1989} \frac{\text { Sales } \text { Pr ice }_{t}}{{\text { MarketValu } e_{t-1}}^{\text {Mark }}}
$$


Table 3. The Determinants of the Number ${ }^{\mathrm{a}}$ of Divestments:

Poisson and Negative Binomial Estimates

\begin{tabular}{|c|c|c|c|c|c|}
\hline Independent variable & (1) & (2a) & (2b) & (2c) & (2d) \\
\hline Constant & $\begin{array}{r}-4.249 \\
* * * * \\
(-4.868)\end{array}$ & $\begin{array}{r}-3.904 \\
* * * \\
(-2.570)\end{array}$ & $\begin{array}{r}-3.814 \\
* * * \\
(-2.695)\end{array}$ & $\begin{array}{r}-3.819 \\
* * * \\
(-2.720)\end{array}$ & $\begin{array}{l}-3.867 \\
* * * * \\
* 2.894)\end{array}$ \\
\hline Accounting performance & $\begin{array}{r}0.075 \\
(0.759)\end{array}$ & $\begin{array}{r}0.026 \\
(0.115)\end{array}$ & & & \\
\hline Relative accounting performance & & & $\begin{array}{r}0.001 \\
(0.084)\end{array}$ & & \\
\hline Market performance & & & & $\begin{array}{r}-0.066 \\
(-0.542)\end{array}$ & \\
\hline Relative shareholder returns & & & & & $\begin{array}{r}-0.005 \\
(1.559)\end{array}$ \\
\hline Firm leverage & $\begin{array}{r}0.532 \\
* * * * \\
(8.392)\end{array}$ & $\begin{array}{r}0.451 \\
* * * * \\
(3.955)\end{array}$ & $\begin{array}{r}0.446 \\
* * *(3.931)\end{array}$ & $\begin{array}{r}0.447 \\
{ }_{* * * *}(3.972)\end{array}$ & $\begin{array}{c}0.418 \\
* * * * \\
(3.310)\end{array}$ \\
\hline Board composition & $\begin{array}{r}0.058 \\
* * *(5.120)\end{array}$ & $\begin{array}{r}0.057 \\
* *(2.046)\end{array}$ & $\begin{array}{r}0.057 \\
* *(2.086)\end{array}$ & $\begin{array}{r}0.058 \\
* *(2.002)\end{array}$ & ${ }^{* *}(1.025)$ \\
\hline Blockholder & $\begin{array}{r}0.136 \\
* *(1.975)\end{array}$ & $\begin{array}{r}0.049 \\
(0.285)\end{array}$ & $\begin{array}{r}0.051 \\
(0.288)\end{array}$ & $\begin{array}{r}0.059 \\
(0.340)\end{array}$ & $\begin{array}{r}0.033 \\
(0.199)\end{array}$ \\
\hline Management equity & $\begin{array}{r}0.070 \\
* * * * \\
(4.652)\end{array}$ & $\begin{array}{r}0.085 \\
* * * * \\
(2.852)\end{array}$ & $\begin{array}{r}0.085 \\
* * *(2.872)\end{array}$ & $\begin{array}{r}0.085 \\
* * * * \\
(2.881)\end{array}$ & ${ }^{* *}(2.0711$ \\
\hline Diversification level & $\begin{array}{r}0.085 \\
* * * * \\
(5.671)\end{array}$ & $\begin{array}{r}0.070 \\
* * * * \\
(3.651)\end{array}$ & $\begin{array}{r}0.069 \\
* * * \\
(3.657)\end{array}$ & $\begin{array}{r}0.074 \\
* * * \\
(3.284)\end{array}$ & $\begin{array}{l}0.065 \\
* * * \\
(3.528)\end{array}$ \\
\hline Firm size & $\begin{array}{r}0.424 \\
* * * * \\
(12.029)\end{array}$ & $\begin{array}{r}0.403 \\
* * *(5.263)\end{array}$ & $\begin{array}{r}0.400 \\
* * *(5.219)\end{array}$ & $\begin{array}{r}0.411 \\
* * *(5.168)\end{array}$ & $\begin{aligned} & 0.412 \\
* * * & (5.071)\end{aligned}$ \\
\hline Market share & $\begin{array}{r}0.447 \\
* * * * \\
(3.313)\end{array}$ & $\begin{array}{r}0.372 \\
(0.890)\end{array}$ & $\begin{array}{r}0.380 \\
(0.907)\end{array}$ & $\begin{array}{r}0.348 \\
(0.790)\end{array}$ & $\begin{array}{r}0.420 \\
(1.042)\end{array}$ \\
\hline Concentration & $\begin{array}{l}-0.705 \\
* * * * \\
(-3.508)\end{array}$ & $\begin{array}{r}-0.595 \\
*-1.673)\end{array}$ & $*(-1.678)$ & $\begin{array}{r}-0.569 \\
(-1.482)\end{array}$ & $\begin{array}{l}-0.691 \\
* * \\
* 2.006)\end{array}$ \\
\hline Change in management & $* * * \begin{array}{r}0.302 \\
(4.040)\end{array}$ & $\begin{array}{r}0.403 \\
* * * \\
(2.332)\end{array}$ & $\begin{array}{l}0.406 \\
* * \\
*(2.331)\end{array}$ & $\begin{array}{l}0.418 \\
* *(2.346)\end{array}$ & $\begin{array}{r}0.370 \\
* *(2.163)\end{array}$ \\
\hline Acquisition & $\begin{array}{r}0.616 \\
(0.840)\end{array}$ & $\begin{array}{r}0.932 \\
(0.749)\end{array}$ & $\begin{array}{r}0.954 \\
(0.765)\end{array}$ & $\begin{array}{r}0.851 \\
(0.683)\end{array}$ & $\begin{array}{r}0.915 \\
(0.784)\end{array}$ \\
\hline $\begin{array}{l}-\ln \mathrm{L} \\
\text { Variance parameter } \alpha\end{array}$ & -491.285 & $\begin{array}{r}-386.568 \\
0.381 \\
* * * *(5.745)\end{array}$ & $\begin{array}{r}-386.572 \\
0.381 \\
* * * *(5.749)\end{array}$ & $\begin{array}{r}-386.376 \\
0.380 \\
* * * *(5.820)\end{array}$ & $\begin{array}{r}-385.202 \\
0.367 \\
* * * * \\
(5.822)\end{array}$ \\
\hline
\end{tabular}

Notes: $\mathrm{n}=134 ; t$-statistics appear in parentheses: ${ }^{*}=p<0.1,{ }^{* *}=p<0.05,{ }^{* * *}=p<0.01$. ${ }^{\mathrm{a}}$ Dependent variable equals: (1) the number of divestments - Poisson model,

(2) the number of divestments - Negative Binomial model. 
The results in Tables 2 and 3 show a considerable consistency across specifications and with either version of the dependent variable. The results across the models are very largely in accord with our prior expectations. Among the variables which were predicted to increase the firm's responsiveness to the capital market and hence accelerate any downward adjustment in diversification, Firm Leverage and the corporate governance variables of Board Composition and Management Equity exercised a significant positive effect in both the proportions and count data models. Alone among the governance variables, only the existence of an identifiable Blockholder failed to attract a significant coefficient.

Turning to the strategy variables, both Diversification Level and Firm Size have a consistently positive and significant effect across each specification. The very large coefficients for these variables in the count data model are not unexpected, given an anticipated mean regression effect. However, their significant performance in the proportions model is consistent with our strategic priors that larger and more diversified firms may have experienced a proportionately greater fall in their optimal levels of diversification. Those firms which experienced a Change in Management displayed a significantly higher extent of divestment, ceteris paribus, using either the proportions or count data models. Finally, the binary variable Acquisition, used to distinguish those firms which made at least one successful acquisition within the quoted sector over the period, was positive but significant only in the proportions model.

The market structural characteristics produced mixed effects. Concentration carried a negative coefficient which was significant to at least the 10 percent level in all specifications. This suggested that location in a cushioned core market tended to reduce any fall in the optimal level of diversification. By contrast, Market Share carried a positive coefficient but was insignificant in every case apart from the Poisson regression which, as we have argued, appears unreliable for our data. As these two variables were moderately strongly correlated $(r=0.59)$ we tried entering them separately, but the same pattern of signs and significance was maintained. Of course, an ambiguous result for Market Share was not entirely surprising; high values for this variable should impact positively upon core activity profitability but will simultaneously restrict the firm's core growth prospects. 
Since our count data models are non-linear, there is some opacity about their estimation. Accordingly, we have calculated the marginal effects (i.e. $\delta \mathrm{E}[\mathrm{y} \mid \mathrm{X}] / \mathrm{X}=\lambda_{\mathrm{i}} \mathrm{b}$ ) for the significant regressors only, using the preferred negative binomial specification of Table 3.The results are given in Table 4. These have been calculated at the mean values of the covariates. They confirm, in particular, the importance of Firm Leverage, Firm Size and a Change in Management in positively affecting divestment and (principal market) Concentration in reducing it.

Table 4. Marginal Effects: the number of divestments - Negative Binomial model

\begin{tabular}{|lrrrr|}
\hline Independent variable & $(2 \mathrm{a})$ & $(2 \mathrm{~b})$ & $(2 \mathrm{c})$ & $(2 \mathrm{~d})$ \\
Firm leverage & 3.040 & 3.012 & 3.010 & 2.811 \\
Board composition & 0.385 & 0.386 & 0.388 & 0.352 \\
Management equity & 0.574 & 0.573 & 0.575 & 0.476 \\
Diversification level & 0.472 & 0.469 & 0.501 & 0.438 \\
Firm size & 2.716 & 2.702 & 2.770 & 2.771 \\
Concentration & -4.016 & -4.080 & -3.840 & -4.645 \\
Change in management & 2.765 & 2.736 & 2.820 & 2.486 \\
\hline
\end{tabular}

Notes: Columns correspond to those in Table 3.

The most surprising result across all specifications of the model was the failure to find a significant firm performance effect. It had been conjectured that when firms experienced a downward shift in optimal diversification, the more poorly performing ones would adjust more rapidly under the implicit threat from the takeover market and this would be observed ceteris paribus in a higher volume of divestment across the interval examined. However, neither own profitability, profitability relative to the industry average nor Tobin's $q$ approached any acceptable level of significance. The latter finding was especially surprising in the sense that a forward-looking performance measure, 
such as Tobin's $q$, relates more obviously to capital market discipline than one such as profitability whose observed values might be expected to display time dependence. Dropping the market structural variables, equivalent to employing a reduced-form version in which market structural effects work through firm performance alone, did nothing to change these results. The nearest each of the models came to producing a significant performance effect was when relative shareholder returns was used as the firm performance measure. Even here the coefficients, although negative, failed to achieve the 10 percent significance level.

Since the results available from the US generally report a significant negative correlation between parent financial performance and voluntary divestment [see Bergh (1997)] our findings appear particularly surprising. Before rejecting the existence of such a link in the UK context we are mindful of two caveats: first, this paper uses a cross sectional design in which the explanatory variables are measured prior to the start of the period of investigation to avoid problems of simultaneity bias. It is possible that the implied lag between the variable's measurement and most subsequent divestment was simply too long - i.e. adjustment may occur quite rapidly [for example, Jain (1985) found that firm performance began to suffer approximately one year prior to divestment] - and averaging the effects across a five year time interval may introduce unnecessary contamination. Second, there is evidence from the merger literature [e.g., Ravenscraft and Scherer (1987) for the US and Meeks (1977) for the UK] that strong financial performance is associated with acquisition activity which may itself generate divestments after some lag. Therefore it is possible that measured performance before the start of our period captures some element of the potential to divest, thus eroding our initial prior.

Some check on the possibility that averaging across a five-year interval was eliminating key relationships was possible by re-estimating the models as yearly cross sections. Given the high proportion of zeros in any year, this tended to produce poorly determined estimations ${ }^{12}$. For the most part, however, these estimations continued to reveal an insignificant firm performance effect. When the previous year's relative stock market returns and Tobin's $q$ were used as the performance measure they did produce a significant negative effect in two years, 1985 and 1986, although not elsewhere. 


\section{SUMMARY AND CONCLUSIONS}

This paper has presented an empirical analysis of divestment activity in the UK, over the period 1985-89, using what we believe to be the most comprehensive database on corporate sell-offs yet assembled. The period was chosen partly because the available evidence indicated that it was when "corporate refocusing" became widespread and because it predated any recession-induced changes that might have been anticipated in the early 1990s.

The analysis of divestment used data on both the number and the aggregate value of sell-offs, giving rise to two complementary models of the divestment process. Taken together these two approaches suggest that firms' divestment behaviour was not merely exhibiting mean reversion in the number of activities operated or simple portfolio churning across the set of such activities. Instead they indicate that divestment was systematically related to leverage, corporate governance, strategy and - to a limited extent - market structural characteristics. The important role for leverage and corporate governance variables is consistent with their impacting upon the speed of adjustment of actual diversification towards lower optimal levels apparently required in the 1980s. They may be considered to proxy the firm's responsiveness to capital market discipline.

The paper's results also indicate that both the value and extent of divestment activity is related to the size and diversification of the firm concerned. This outcome holds for the proportions model as well as the count data one, indicating that it is not merely a mean reversion process. The finding is consistent with the view from a corporate strategy perspective that gains from divestment will be greatest for those firms experiencing control problems associated with size and diversity. Senior managerial changes and - less distinctly - acquisition activity over the period of investigation also appear to stimulate divestment. The effect of market structural factors appears more ambiguous with core activity concentration having a weakly significant inhibiting effect and market share producing no significant effect at all.

\footnotetext{
12 The proportions model results were particularly badly determined, no doubt a consequence of the lumpiness or indivisibility attaching to potentially divestable activities. The count data results were somewhat better. These are available from the authors upon request.
} 
Rather surprisingly, in view of much of the US evidence, the results failed to reveal any significant association between firm performance and divestment. It had been conjectured that poor performance, like high leverage and a strict corporate governance regime, would encourage rapid adjustment to lower diversification and hence lead to a high observed extent of divestment. It is possible that the cross sectional design employed here influenced this outcome by requiring firm performance to be measured too far ahead of actual divestment decisions. It is also possible that prior firm performance picks up other characteristics, including past merger activity, with implications for divestment.

These results, as far as the authors are aware, represent the first attempt to analyse the determinants of divestment behaviour in the UK. Thus far, the labour-intensive character of data collection on divestment and diversification has restricted us to a cross sectional design with its inevitable limitations. Further work is being undertaken, using a panel design, to explore more fully both the determinants and consequences of divestment and refocusing activity. 


\section{Appendix A}

\section{Independent Variables}

Firm performance was measured using a variety of accounting- and market-based variables, as follows:

Accounting Performance. Accounting-based firm performance is calculated using three different measures: return on capital employed (ROCE), return on equity (ROE), and return on sales (ROS). Following Markides (1995b), industry-weighted performance figures are also calculated. The following procedure is adopted: first, a Datastream programme was used to identify all firms assigned to a Datastream industry (this is roughly equivalent to the 3-digit SIC level of aggregation). Second, the constituents of the ratios were summed for all firms within an industry and the industry ratio was calculated on the summed values. For example, an industry aggregation of ROS represents the sum of operating profits of companies within that sector divided by the sum of the companies' sales. This method improves accuracy because the aggregation is not distorted by extreme values within a single company. Third, the industry-weighted ROS for each firm in the sample is calculated by subtracting the industry's ROS from the firm's ROS. Similarly, for industryweighted ROCE and ROE.

Market Performance. Market performance is alternatively measured as the ratio of market value to book value of assets (an approximation to Tobin's $q$ ).

Shareholder Returns. Shareholder returns for each company is extracted on an annual basis from Datastream. The Returns Index (RI) is calculated as follows: $\mathrm{RI}_{t}=\mathrm{P}_{t}-\mathrm{P}_{t-1}+\mathrm{d} / \mathrm{P}_{t-1}$, where $\mathrm{P}_{t}$ is price of the share in time $t, \mathrm{P}_{t-1}$ is the price in $t-1$ and $\mathrm{d}$ is dividend per share. To calculate shareholder returns relative to the market, the returns index for the FT Allshare is subtracted from each firm's returns index.

Firm Leverage. Firm leverage is measured as the ratio of debt-to-total assets and the ratio of debtto-equity, both measured as book values. 
The corporate governance variables used were as follows:

Management Equity Interests. Management equity interests is calculated as the percentage of total outstanding ordinary shares owned by the directors of the firm.

Blockholder Ownership. We represent blockholder ownership (here defined as the ownership of 5 per cent or more of the firm's ordinary shares by a single shareholder) by a dichotomous variable equal to 1 if there was a blockholder immediately prior or during the period and 0 otherwise.

Board Composition. Representation of outsiders on a board is calculated as the ratio of nonexecutive to executive board members. Non-executive directors or outside directors are defined as directors with no personal relationship with a firm other than the position of director. Executive directors are current managers of the firm.

Diversification Level. Firm diversification is measured using the entropy index (Palepu, 1985): entropy index $=\Sigma \mathrm{P}_{i} \ln \left(1 / \mathrm{P}_{i}\right)$, where $\mathrm{P}_{i}$ is the share of the $i$ th segment in the total sales of the firm and $\ln \left(1 / \mathrm{P}_{i}\right)$ is the weight for each segment $i$. The index was calculated using sales data and SIC codes for each of the principal segments of the company at the 3-digit level. In the cases where it was not possible to assign a unique SIC code to a segment, the sales were split evenly between two SIC codes assigned to that segment.

Firm Size. Firm size is calculated by taking the book value of total assets, total sales, and the number of employees.

Market Share. Market share is calculated as total sales of a firm divided by industry sales.

Concentration. Concentration was measured by the Herfindahl index which is calculated as the sum of the squared market shares of the firms in an industry. 
Change in Top Management. This is measured using a dichotomous variable equal to 1 if there was a change in Managing Director/CEO (or equivalent) immediately prior or during the period and 0 otherwise.

Acquisition. Acquisition is measured as a dichotomous variable equal to 1 if there was a recorded acquisition over the period and 0 otherwise. 


\section{REFERENCES}

Amihud, Y. and Lev, B. (1981), 'Risk Reduction as a Motive for Conglomerate Mergers', Bell Journal of Economics, 12, 605-617

Barney, J.B. (1986), 'Strategic Factor Markets: Expectations, Luck and Business Strategy', Management Science, 32, 1231-1241

Bergh, D.D. (1997), 'Predicting Divestiture of Unrelated Acquisitions: An Integrative Model of Ex Ante Conditions', Strategic Management Journal, 18(9), 715-731

Bhagat, S., Shleifer, A. and Vishny, R. (1990), 'Hostile Takeovers in the 1980s: The Return to Corporate Specialisation', Brookings Papers on Economic Activity, Microeconomics 1990, 1-84

Bhide, A. (1990), 'Reversing Corporate Diversification', Journal of Applied Corporate Finance, 3(2), 70-81

Cameron, A.C. and Trivedi, P.K. (1986), 'Econometric Models Based on Count Data: Comparisons and Applications of some Estimators and Tests', Journal of Applied Econometrics, 1, 29-53

Cameron, A.C. and Trivedi, P.K. (1990), 'Regression-based Tests for Overdispersion in the Poisson Model', Journal of Econometrics, 46, 347-364

Chang, S.J. (1996), 'An Evolutionary Perspective on Diversification and Corporate Restructuring: Entry, Exit and Economic Performance', Strategic Management Journal, 17, 587-611

Chatterjee, S. and Wernerfelt, B., (1991), 'The Link Between Resources and the Type of Divestment: Theory and Evidence', Strategic Management Journal, 12, 33-48

Denis, D.J., Denis, D.K. and Sarin, A. (1997), 'Agency Problems, Equity Ownership and Corporate Diversification', Journal of Finance, 52, 135-160

Geroski, P. and Gregg, P. (1997), Coping With Recession: UK Company Performance in Adversity, Cambridge University Press: Cambridge

Gibbs, P.A. (1993), 'Determinants of Corporate Restructuring: The Relative Importance of Corporate Governance, Takeover Threat, and Free Cash Flow', Strategic Management Journal, 14, 51-68

Gollop, F. and Monahan, J. (1991), 'A Generalized Index of Diversification: Trends in US Manufacturing', Review of Economics and Statistics, 73, 318-330

Hausman, J., Hall, B.H. and Griliches, Z. (1984), 'Econometric Models for Count Data with an Application to the Patents-R\&D Relationship', Econometrica, 52(4), 909-938

Hoskisson, R.E., Johnson, R.A. and Moesel, D.D. (1994), 'Corporate Divestiture Intensity in Restructuring Firms: Effects of Governance, Strategy and Performance', Academy of Management Journal, 37(5), 1207-1251

Hoskisson, R.E. and Turk, T.A. (1990), 'Corporate Restructuring: Governance and Control Limits of the Internal Capital Market', Academy of Management Review, 15(3), 459477

Ingham, H. and Thompson, S. (1995), 'Deregulation, Firm Capabilities and Diversifying Entry Decisions', Review of Economics and Statistics, 77, 177-183 
Jain, P. (1985), 'The Effect of Voluntary Sell-off Announcements on Shareholder Wealth', Journal of Finance, 40(1), 209-224

Jensen, M. (1986), 'Agency Costs of Free Cash Flow, Corporate Finance, and Takeovers', American Economic Review Papers and Proceedings, 76(2), 323-329

Johnson, R.A., Hoskisson, R.E. and Hitt, M.A. (1993), 'Board of Director Involvement in Restructuring: The Effects of Board Versus Managerial Controls and Characteristics', Strategic Management Journal, 14, 33-50

Kaplan, S.N. and Weisbach, M.S. (1992), 'The Success of Acquisitions: Evidence from Divestitures', Journal of Finance, 47, 107-138

Lang, L.H. and Stulz, R.M. (1994), 'Tobin's Q, Corporate Diversification and Firm Performance', Journal of Political Economy, 102(6), 1248-1280

Markides, C. (1995a), Diversification, Refocusing and Economic Performance. MIT Press

Markides, C. (1995b), 'Diversification, Restructuring and Economic Performance', Strategic Management Journal, 16, 101-118

Meeks, G (1977), Disappointing Marriage: A Study of the Gains From Merger, Department of Applied Economics, University of Cambridge.

Morck, R., Shleifer, A. and Vishny, R. (1990), 'Do Managerial Objectives Drive Bad Acquisitions?', Journal of Finance, 45, 31-48

Mueller, D. C. (1969), ‘A Theory of Conglomerate Mergers', Quarterly Journal of Economics, 83, 643-51

Palepu, K. (1985), 'Diversification Strategy, Profit Performance and the Entropy Measure', Strategic Management Journal, 6, 239-255

Palepu, K. (1986), 'Predicting Takeover Targets: A Methodological and Empirical Analysis', Journal of Accounting and Economics, 8, 3-35

Penrose, E. (1959), The Theory of the Growth of the Firm. Basil Blackwell: Oxford

Ravenscraft, D.J. and Scherer, F.M. (1987), Mergers, Sell-offs and Economic Efficiency. The Brookings Institution, Washington, DC

Rumelt, R.P. (1974), Strategy, Structure and Economic Performance, Cambridge, MA: Harvard University Press

Servaes, H. (1996), 'The Value of Diversification during the Conglomerate Merger Wave', Journal of Finance, 51, 1201-1225

Shleifer, A. and Vishny, R.W. (1991), 'Takeovers in the '60s and the '80s: Evidence and Implications', Strategic Management Journal, 12, 51-59

Shleifer, A. and Vishny, R.W. (1997), 'A Survey of Corporate Governance', Journal of Finance, 52, 737-783

Teece, D. (1982), 'Towards an Economic Theory of the Multiproduct Firm', Journal of Economic Behaviour and Organisation, 3, 39-63

Wernerfelt, B. (1984), 'A Resource-Based View of the Firm', Strategic Management Journal, 5, 171-180

Wernerfelt, B. and Montgomery, C. (1988), 'Tobin's $q$ and the Importance of Focus in Firm Performance', American Economic Review, 78, 246-50 
Williamson, O. E. (1975), Markets and Hierarchies: Analysis and Antitrust Implications. New York Press

Wright, M., Robbie, K., Thompson, S. and Starkey, K. (1994), 'Longevity and the Life-Cycle of Management Buy-outs', Strategic Management Journal, 15(3), 215-227 